\title{
Mesorhizobium gobiense sp. nov. and Mesorhizobium tarimense sp. nov., isolated from wild legumes growing in desert soils of Xinjiang, China
}

Correspondence

Wen Xin Chen

wenxin@cau.edu.cn

\author{
Tian Xu Han, ${ }^{1}$ Li Li Han, ${ }^{1}$ Li Juan Wu, ${ }^{1}$ Wen Feng Chen, ${ }^{1}$ Xin Hua Sui, ${ }^{1}$ \\ Jin Gang Gu, ${ }^{3}$ En Tao Wang ${ }^{1,2}$ and Wen Xin Chen ${ }^{1}$ \\ ${ }^{1}$ Key Laboratory of Agro-Microbial Resource and Application, Ministry of Agriculture/College of \\ Biological Sciences, China Agricultural University, Beijing 100193, PR China
${ }^{2}$ Departamento de Microbiología, Escuela Nacional de Ciencias Biológicas, Instituto Politécnico Nacional, 11340 México DF, México
${ }^{3}$ The Institute of Agricultural Resources and Regional Planning of Chinese Academy of Agricultural Sciences. Beijing 100081, PR China

Twenty-four Mesorhizobium strains were isolated from desert soils in the Xinjiang region of China and were characterized by a polyphasic approach. These strains grouped into three clusters in IGS-RFLP, SDS-PAGE analysis of whole-cell proteins and BOX-PCR analysis, corresponding to genomic species $\mathrm{V}, \mathrm{VI}$ and $\mathrm{VII}$ as found in a previous study. The results were supported by sequencing analyses of $r r s$, IGS, atpD and recA genes. Genospecies VII was most related to Mesorhizobium septentrionale, while genospecies $\mathrm{V}$ and $\mathrm{VI}$ were both most closely related to Mesorhizobium tianshanense, but were distinct from each other and from M. tianshanense. The DNA-DNA hybridization value between the representative strain CCBAU 83284 (genospecies VII) and the type strain of $M$. septentrionale was $90.1 \%$. Genospecies VII was thus defined as $M$. septentrionale. The DNA-DNA relatedness value for representative strains of genospecies $\mathrm{V}$ or $\mathrm{VI}$ with the related reference strains of recognized species were always lower than $60 \%$. Low values of DNA-DNA hybridization (32.79\%) between representative strains of genospecies V (CCBAU $\left.83330^{\top}\right)$ and of VI (CCBAU $83306^{\top}$ ) were also observed. Based upon these results, two novel species are proposed: Mesorhizobium gobiense sp. nov. represented by genospecies $\mathrm{V}$ (type strain, CCBAU $83330^{\top}=$ LMG $23949^{\top}=$ HAMBI $2974^{\top}$ ) and Mesorhizobium tarimense sp. nov. represented by genospecies VI (type strain, CCBAU $83306^{\top}=$ LMG $24338^{\top}=$ HAMBI $2973^{\top}$ ). Strain CCBAU 83278 grouped as the most peripheral member with genospecies VI in SDSPAGE of whole-cell proteins and BOX-PCR analysis and in the phylogenetic tree of 16S-23S rRNA intergenic spacer (IGS) sequences. The results of analyses of $r r s$, atp $D$ and recA gene sequences, as well as those of DNA-DNA hybridization studies, strongly supported the suggestion that this strain belonged to a species quite different from genospecies $\mathrm{V}$ and $\mathrm{VI}$ and from any other recognized species of the genus Mesorhizobium. As only one strain has been

\begin{abstract}
Abbreviations: ARDRA, amplified rDNA restriction analysis; BOX-PCR, BOX-repeat-based PCR; IGS, 16S-23S rRNA intergenic spacer.
The GenBank/EMBL/DDBJ accession numbers for the 16S rRNA gene sequences for M. gobiense sp. nov. strains CCBAU $83330^{\top}$, CCBAU 83511 and CCBAU 83346, M. tarimense sp. nov. strains CCBAU 83306 ${ }^{\top}$ and CCBAU 83321, strain CCBAU 83278 and M. septentrionale strains CCBAU 83281 and 83284 are EF035064, EF549381, EF549388, EF035058, EF549387, EU368831, EF549379 and EF035063, respectively. Those for partial IGS are EF050768, EF549537, EF050769, EF050771, EF050772, EF050770, EF549535 and EF050773, respectively. Accession numbers for the partial atpD gene sequences are EF549409, EF549411, EF549413, EF549410, EF549412, EU371996, EF549407 and EF549415, respectively. For partial recA gene sequences, the accession numbers are EF549481, EF549480, EF549478, EF549482, EF549479, EU371997, EF549484 and EF549485, respectively. The partial nodC gene sequences are EF050784, EF549525, EF549524, EF050786, EF549514, EF549527, EF549511 and EF050783, respectively. The partial nifH gene sequences are EU252606, EU252604, EU252605, EU252607, EU252608, EU252603, EU252601 and EU252602, respectively.
\end{abstract}

Dendrograms constructed from IGS-RFLP, BOX-PCR and SDS-PAGE analyses and additional phylogenetic trees based on IGS, atpD, recA, nodC and nifH gene sequences are available as supplementary figures with the online version of this paper. A supplementary table giving details of cellular fatty acid contents is also available. 
isolated to date, strain CCBAU 83278 was not proposed as a novel species in this study. Mesorhizobium gobiense sp. nov. and Mesorhizobium tarimense sp. nov. could be differentiated from each other as well as from recognized species of the genus Mesorhizobium on the basis of phenotypic characteristics. The symbiotic loci ( $\operatorname{cod} \mathrm{C}$ and nifH) of the two novel species formed two phylogenetic branches related to Mesorhizobium loti and M. tianshanense. The type strains of the two novel species were able to nodulate Glycyrrhiza uralensis, Lotus corniculatus, Oxytropis glabra and Robinia pseudoacacia but not Astragalus membranaceus, Leucaena leucocephala, Phaseolus vulgaris, Pisum sativum or Medicago sativa.

The family Leguminosae is one of the largest families of green plants, containing more than 17900 species distributed throughout the world (Allen \& Allen, 1981). Most legume species have a unique and important characteristic that enables them to form nodules on roots and/or stems and establish symbiosis with soil bacteria, collectively called rhizobia. Within nodules, rhizobia reduce $\mathrm{N}_{2}$ to ammonia which can then be used by the legume plants. Due to the ecological and economic importance of rhizobia, their diversity has been extensively investigated and rhizobial taxonomy has been greatly improved in the last two decades. So far, more than 50 species of rhizobia have been reported (Wang et al., 2006). In China, a total of 1485 leguminous species in 172 genera have been recorded and they are distributed in the tropical, subtropical, temperate and frigid climate zones, from the south to the north (Wang et al., 2007). Diverse rhizobia isolated from Chinese legumes have been characterized and several novel species have been proposed (Chen et al., 1988, 1991, 1997; Gao et al., 2004; Scholla \& Elkan, 1984; Tan et al., 2001; van Berkum et al., 1998; Wang et al., 1999, 2007; Wei et al., 2002, 2003; Xu et al., 1995; Yao et al., 2002).

Xinjiang is the largest province of China and has an area of 1.66 million $\mathrm{km}^{2}$, roughly $1 / 6$ of the total Chinese territory. Most of Xinjiang is covered by desert. It has a typical continental climate, with low rainfall but very high evaporation potential. The soils in this area are poor in organic matter with high salinity and alkalinity (Chen et al., 1995). In a previous study (Han et al., 2008), we characterized 111 rhizobial strains isolated from multiple wild legume species growing natively in Xinjiang by amplified rDNA restriction analysis (ARDRA) and sequence analysis of $16 \mathrm{~S}$ rRNA genes (data not shown). Twenty-four of the strains that were isolated from the nodules of Astragalus filicaulis, Lotus frondosus, Lotus tenuis, Oxytropis glabra and Robinia pseudoacacia (Table 1) were classified within the genus Mesorhizobium based on ARDRA. These 24 strains formed three genomic species and genospecies $\mathrm{V}$ and VI were phylogenetically closely related to Mesorhizobium tianshanense, while genospecies VII was closely related to both Mesorhizobium amorphae and Mesorhizobium septentrionale. In this study, these strains were further analysed to clarify their taxonomic status by 16S-23S rRNA intergenic spacer (IGS) RFLP (IGSRFLP), SDS-PAGE analysis of whole-cell proteins, BOXrepeat-based PCR (BOX-PCR) fingerprinting, analysis of phenotypic characteristics, DNA-DNA hybridization and sequence analyses of $r r s$, IGS, atpD, recA, nodC and nifH genes.

IGS-RFLP, considered to be a useful tool for investigating the relatedness of closely allied rhizobial strains (Jensen et al., 1993; Vinuesa et al., 1998; Laguerre et al., 1996), was performed with the primers FGPS1490 (Navarro et al., 1992)/FGPL132' (Ponsonnet \& Nesme, 1994) and MboI, MspI and $A l u \mathrm{I}$ restriction endonucleases. The results showed that the test strains formed three clusters corresponding to the three genomic species defined in the previous study at a similarity of $76 \%$ at which all the reference strains were distinguished according to their species (see Supplementary Fig. S1 in IJSEM Online). Genomic species VII contains four strains isolated from Robinia pseudoacacia and was found to cluster with $M$. amorphae and $M$. septentrionale, indicating that these species are closely related to genomic species VII. In contrast, genomic species $\mathrm{V}$ and VI formed a cluster that was separate and distinct from the recognized species of the genus Mesorhizobium analysed here, suggesting that they may represent two novel species.

SDS-PAGE of whole-cell proteins was conducted according to a previously described method (Tan et al., 1997). The normalized densitometric traces of the electrophoretic protein patterns were grouped using the Gelcompar II software package (Applied Maths). The similarity between each pair of samples (strains) was expressed by DICE and an UPGMA dendrogram was constructed (Vauterin \& Vauterin, 1992). All the test strains in the SDS-PAGE analysis of whole-cell proteins formed three clusters corresponding to genomic species V, VI, and VII, respectively, at a similarity level of $87 \%$, where all the reference strains of Mesorhizobium included in the study could be well separated (see Supplementary Fig. S2 in IJSEM Online). Genospecies VII clustered with $M$. septentrionale at a similarity level of about $87.5 \%$, implying that this genospecies belongs to $M$. septentrionale. Genospecies V and VI produced different protein patterns from those of the strains for recognized Mesorhizobium species at the similarity level of $87 \%$.

To reveal the genetic diversity of the novel isolates, BOXPCR was performed using the BOXAIR primer (Versalovic et al., 1994). PCRs were carried out as described by Nick \& Lindström (1994). The fingerprints were analysed by the Gelcompar II program (Applied Maths) and an UPGMA 
Table 1. Isolates and reference strains used in this study

\begin{tabular}{|c|c|c|}
\hline Strains & Host plant & Geographical origin \\
\hline \multicolumn{3}{|l|}{ M. septentrionale (genomic species VII) } \\
\hline CCBAU 83281, CCBAU 83282, CCBAU 83284, CCBAU 83285 & Robinia pseudoacacia & Xinjiang, China \\
\hline \multicolumn{3}{|l|}{ M. gobiense sp. nov. (genomic species VI) } \\
\hline CCBAU 83508, CCBAU 83509, CCBAU 83511 & Astragalus filicaulis & Xinjiang, China \\
\hline CCBAU 83307, CCBAU 83310, CCBAU 83341, CCBAU 83342 & Lotus frondosus & Xinjiang, China \\
\hline CCBAU 83346 & Lotus tenuis & Xinjiang, China \\
\hline CCBAU 83329, CCBAU $83330^{\mathrm{T}}$, CCBAU 83331 & Oxytropis glabra & Xinjiang, China \\
\hline \multicolumn{3}{|l|}{ M. tarimense sp. nov. (genomic species V) } \\
\hline $\begin{array}{l}\text { CCBAU } 83306^{\mathrm{T}} \text {, CCBAU } 83308, \text { CCBAU } 83311, \text { CCBAU } 83312, \text { CCBAU } 83339 \text {, } \\
\text { CCBAU } 83338, \text { CCBAU } 83343\end{array}$ & Lotus frondosus & Xinjiang, China \\
\hline CCBAU 83321 & Lotus tenuis & Xinjiang, China \\
\hline \multicolumn{3}{|l|}{ Mesorhizobium sp. (genomic species V) } \\
\hline CBAU 83278 & Robinia pseudoacacia & Xinjiang, China \\
\hline \multicolumn{3}{|l|}{ Reference strains } \\
\hline M. loti NZP $2213^{\mathrm{T}}$ & Lotus corniculatus & New Zealand \\
\hline M. loti NZP 2234 & Lotus corniculatus & New Zealand \\
\hline M. plurifarium LMG $11892^{\mathrm{T}}$ & Acacia senegal & Senegal \\
\hline M. amorphae ACCC $19665^{\mathrm{T}}$ & Amorpha fruticosa & Beijing, China \\
\hline M. chacoense LMG $19008^{\mathrm{T}}$ & Prosopis alba & Argentina \\
\hline M. ciceri USDA $3378^{\mathrm{T}}$ & Cicer arietinum & Spain \\
\hline M. huakuii CCBAU $2609^{\mathrm{T}}$ & Astragalus sinicus & Nanjing, China \\
\hline M. tianshanense CCBAU $3306^{\mathrm{T}}$ & Glycyrrhiza uralensis & Xingjiang, China \\
\hline M. septentrionale SDW014 ${ }^{\mathrm{T}}$ & Astragalus adsurgens & Liaoning, China \\
\hline M. temperatum SDW $018^{\mathrm{T}}$ & Astragalus adsurgens & Liaoning, China \\
\hline M. mediterraneum USDA $3392^{\mathrm{T}}$ & Cicer aretinum & Spain \\
\hline
\end{tabular}

dendrogram was constructed as described above. BOXPCR is a high resolution molecular fingerprinting method that is able to distinguish closely related isolates up to the intraspecies level (Cho \& Tiedje, 2000; Healy et al., 2005; Rademaker et al., 2000). In this analysis, 16 BOX patterns were produced among 24 test strains, revealing a high genetic diversity (see Supplementary Fig. S3 in IJSEM Online). Three corresponding clusters were observed. Genospecies V and VI were clearly separated from all the recognized species of the genus Mesorhizobium used in the BOX-PCR analysis. These results were in an agreement with those of the IGS-RFLP and SDS-PAGE analyses described above.

The 16S rRNA gene and IGS sequence of representative strains for each genomic species were amplified with the primers P1/P6 (Chen et al., 1995) for rrs and FGPS1490 (Navarro et al., 1992)/FGPL132' (Ponsonnet \& Nesme, 1994) for IGS. The $a t p D$ and $r e c A$ genes of the representative strains were also amplified and sequenced by using the method of Vinuesa et al. (2005a, b), with primer sets atpD255F/atpD782R and recA41F/recA640R, respectively. The sequencing of partial nod $C$ and nifH genes of representative strains was performed with the primers nodCfor540/nodCrev1160 of Sarita et al. (2005) and nifH1F/nifH1R of Rivas et al. (2002), respectively. The PCR protocol for the nifH gene was as described by Rivas et al. (2002), while that for the nodC gene was as following: an initial denaturation at $95{ }^{\circ} \mathrm{C}$ for $5 \mathrm{~min}, 30$ cycles of denaturation at $94{ }^{\circ} \mathrm{C}$ for $45 \mathrm{~s}$, annealing at 56-52 ${ }^{\circ} \mathrm{C}$ with $-0.1{ }^{\circ} \mathrm{C} \mathrm{s}^{-1}$ for $40 \mathrm{~s}$, and extension at $72{ }^{\circ} \mathrm{C}$ for $45 \mathrm{~s}$; and final extension at $72{ }^{\circ} \mathrm{C}$ for $6 \mathrm{~min}$. All the amplified fragments of each gene were directly sequenced as described previously (Hurek et al., 1997). These sequences were compared with those held in the GenBank database. All the sequences obtained from this work and from the GenBank database were aligned using CLUSTAL w software (Thompson et al., 1994). The distances were calculated according to the Jukes \& Cantor (1969), the Kimura two-parameter (Kimura, 1983), Tajima \& Nei (1984) and Tamura \& Nei (1993) models. Phylogenetic trees were reconstructed using the neighbour-joining (Saitou \& Nei, 1987), minimum-evolution (Rzhetsky \& Nei, 1993) and maximum-parsimony (Swofford, 1993) methods. Bootstrap analysis was based on 1000 replications. All of the trees were analysed by the MEGA3 package (Kumar et al., 2004). As no significant topological differences were found among the phylogenetic trees obtained by the different methods assayed, only those trees constructed by using the neighbour-joining method after distance analysis of aligned sequences according to the Jukes \& Cantor model are shown.

In the present study, strains CCBAU $83330^{\mathrm{T}}$, CCBAU 83346 and CCBAU 83511 representing genospecies $\mathrm{V}$, strains CCBAU $83306^{\mathrm{T}}$, CCBAU 83321 and CCBAU 83278 representing genospecies VI, and strains CCBAU 83281 and CCBAU 83284 representing genospecies VII were selected for sequence analyses of $16 \mathrm{~S}$ rRNA, IGS, atpD, 


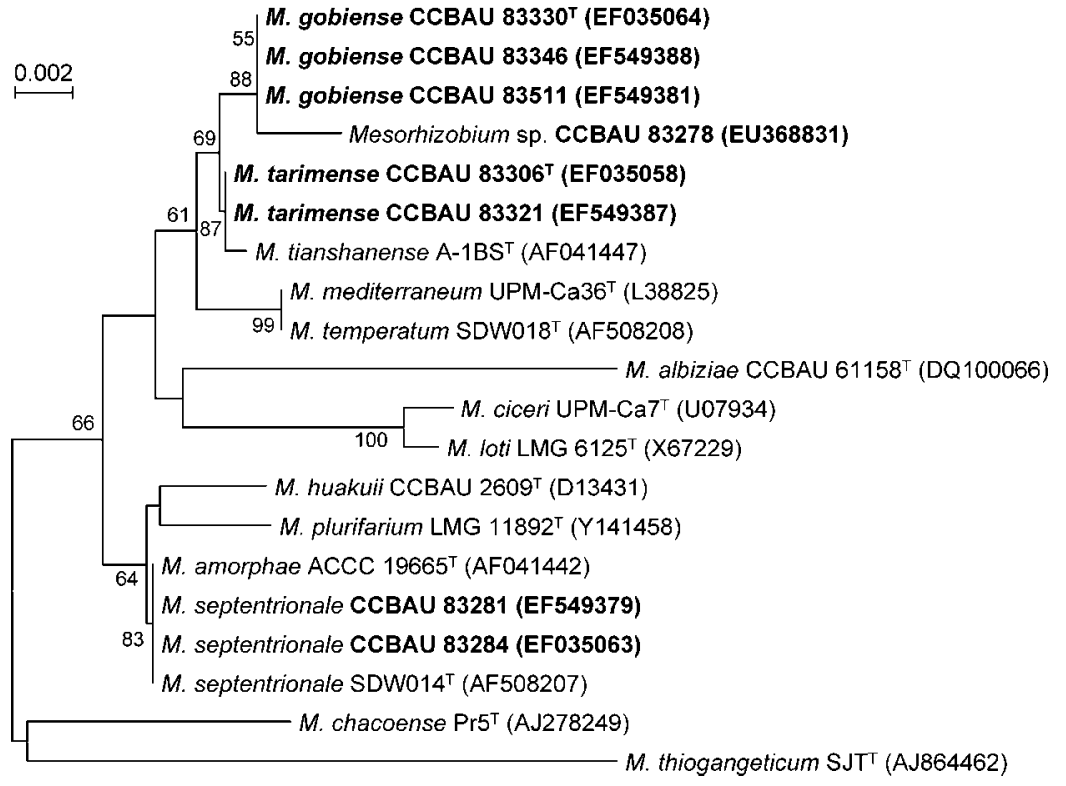

Fig. 1. Phylogenetic tree based on $16 \mathrm{~S}$ rRNA gene sequences showing the relationships among $M$. gobiense sp. nov., $M$. tarimense sp. nov. and the reference strains for recognized species of the genus Mesorhizobium. The neighbour-joining tree was derived from a 16S rRNA gene sequence distance matrix (Jukes-Cantor). Bootstrap confidence levels $\geqslant 50 \%$ are indicated at the nodes. Bar, $0.2 \%$ nucleotide substitutions.
recA, nodC and nifH genes. The phylogenetic trees for each locus are shown in Fig. 1 and Supplementary Figs S4-S8 (available in IJSEM Online). The strains of each genomic species had almost identical 16S rRNA gene sequences, except for strain CCBAU 83278 which showed a similarity level of only $99.01 \%$ with the other two representative strains of genospecies VI as calculated from a $1327 \mathrm{bp}$ sequence. Strain CCBAU 83284 had an identical 16S rRNA gene sequence to both $M$. amorphae and M. septentrionale for the sequenced IGS region. Further analyses of the IGS, $a t p D$ and $r e c A$ gene sequences clearly supported the observation that genospecies VII was most related to $M$. septentrionale. Strain CCBAU $83330^{\mathrm{T}}$ shared $99.85 \% 16 \mathrm{~S}$ rRNA gene sequence similarity with strain CCBAU $83306^{\mathrm{T}}$. $M$. tianshanense was the closest species to both strains CCBAU $83330^{\mathrm{T}}$ and CCBAU $83306^{\mathrm{T}}$, with $16 \mathrm{~S}$ rRNA gene sequence similarity values of $99.77 \%$ and $99.92 \%$, respectively. These data indicate that genospecies V, VI and $M$. tianshanense are the most closely related species; this was also confirmed by the phylogenetic analyses based on IGS, atpD and $r e c A$ gene sequences. It should be noted that strain CCBAU 83278 formed quite separate lineages in the phylogenetic trees based on atpD and recA gene sequences. This could be explained by the fact that strain CCBAU 83278 is the most peripheral member of genospecies VI in BOXPCR and SDS-PAGE analyses and in the phylogenetic tree based on IGS sequences. These results indicated that strain CCBAU 83278 belongs to a different species from strain CCBAU $83306^{\mathrm{T}}$ and from any of the recognized species of the genus Mesorhizobium. Strain CCBAU 83278 was analysed further by DNA-DNA hybridization experiments.

The symbiotic genes (nod and nif) of rhizobia are adaptive genes that in many cases have an evolutionary history independent of the housekeeping genes (Wang et al., 2007). A comparison of their phylogenies with those derived from housekeeping genes may reveal lateral gene transfer events among rhizobia (Haukka et al., 1998). In the present study, nodC and nifH gene fragments were amplified by PCR from the strains with different host plants and were sequenced directly as described above. In the phylogenetic tree based on the nodC gene (see Supplementary Fig. S7 in IJSEM Online), strains CCBAU 83306 ${ }^{\mathrm{T}}$, CCBAU 83321, CCBAU 83511 and CCBAU 83346 clustered with $M$. tianshanense and strain CCBAU $83330^{\mathrm{T}}$ clustered with Mesorhizobium loti. Strains CCBAU 83281 and CCBAU 83284, as well as strain CCBAU 83278, which were isolated from Robinia pseudoacacia, formed a separate lineage that was most closely related to the M. amorphae/Mesorhizobium huakuii lineage. Generally, the nifH gene-based tree (see Supplementary Fig. S8 in IJSEM Online) showed similar phylogenetic relationships to that based on the nodC gene sequences. The exception was that strain CCBAU 83511, isolated from Astragalus filicaulis, was closest to $M$. tianshanense in the nifH gene-based phylogenetic tree but was closest to $M$. loti in the nodC genebased phylogenetic tree.

Since DNA-DNA hybridization is considered as a standard method for species definition (Wayne et al., 1987; Graham et al., 1991), representative strains CCBAU $83306^{\mathrm{T}}$, CCBAU 83321, CCBAU 83278, CCBAU $83330^{\mathrm{T}}$, CCBAU 83521, CCBAU 83346, CCBAU 83284 and related reference strains were chosen for hybridization assays. Total DNA was extracted from each strain by the method of Marmur (1961). DNA-DNA hybridization was performed using the spectrophotometric method (De Ley, 1970). The G+C content of the DNA was measured using the thermal denaturation method of Marmur \& Doty (1962) using Escherichia coli $\mathrm{K}-12$ as the standard. The hybridization values among the representative strains and the reference strains for the related recognized species of the genus Mesorhizobium are summarized in Table 2. Except for strain CCBAU 83278, the DNA-DNA relatedness values 
Table 2. Values for DNA-DNA hybridization (\%) among the representative strains for the novel groups and the reference strains for recognized species of the genus Mesorhizobium

\begin{tabular}{|c|c|c|c|c|c|c|c|}
\hline \multirow[t]{2}{*}{ Strains } & \multicolumn{7}{|c|}{ Hybridization (\%) with DNA from: } \\
\hline & $1^{*}$ & 2 & $3^{*}$ & $4^{\star}$ & 5 & 6 & CCBAU 83284 \\
\hline 1. M. tarimense sp. nov. CCBAU $83306^{\mathrm{T}}$ & & & 17.04 & 32.79 & & & \\
\hline 2. M. tarimense sp. nov. CCBAU 83321 & 85.91 & & & & & & \\
\hline 3. Mesorhizobium sp. CCBAU 83278 & 31.03 & 37.82 & & & & & \\
\hline 4. M. gobiense sp. nov. CCBAU $83330^{\mathrm{T}}$ & 32.79 & & 41.44 & & & & \\
\hline 5. M. gobiense sp. nov. CCBAU 83511 & & & & 100.0 & & & \\
\hline 6. M. gobiense sp. nov. CCBAU 83346 & & & & 78.17 & & & \\
\hline M. tianshanense CCBAU $3306^{\mathrm{T}}$ & 43.45 & 61.52 & 34.52 & 57.45 & 49.26 & 56.85 & \\
\hline M. mediterraneum USDA $3392^{\mathrm{T}}$ & 27.23 & & 3.16 & 51.66 & & & \\
\hline M. temperatum $\mathrm{SDW} 018^{\mathrm{T}}$ & 12.07 & & 17.68 & 30.57 & & & \\
\hline M. amorphae ACCC $19665^{\mathrm{T}}$ & 24.42 & & 8.45 & 40.94 & & & 60.4 \\
\hline M. septentrionale SDW014 ${ }^{\mathrm{T}}$ & 56.02 & & 34.0 & 43.42 & & & 90.1 \\
\hline M. loti NZP $2213^{\mathrm{T}}$ & 17.64 & & & 25.3 & & & \\
\hline M. loti NZP 2227 & 24.24 & & & 17.3 & & & \\
\hline
\end{tabular}

${ }^{\star}$ Data are mean values of at least five repetitions while the others are for 2-3 repetitions.

among the representative strains of each genomic species were always higher than $70 \%$, ranging from $78.2 \%$ to $100 \%$. However, genospecies VI strain CCBAU 83278 shared low DNA-DNA relatedness with strains CCBAU $83306^{\mathrm{T}}(31.03 \%)$ and CCBAU 83321 (37.82\%), which was in agreement with the results of sequence analyses and strongly suggested that they are distinct species. Strains CCBAU $83306^{\mathrm{T}}$, CCBAU 83278, CCBAU $83330^{\mathrm{T}}$ and CCBAU 83284 were further hybridized with M. tianshanense CCBAU $3306^{\mathrm{T}}$, Mesorhizobium temperatum SDW018 ${ }^{\mathrm{T}}$, Mesorhizobium mediterraneum USDA $3392^{\mathrm{T}}$, M. septentrionale SDW014 ${ }^{\mathrm{T}}$, M. amorphae ACCC $19665^{\mathrm{T}}$, M. loti NZP $2213^{\mathrm{T}}$ and $M$. loti NZP 2234. The DNA-DNA relatedness values of strain CCBAU 83284 with $M$. amorphae ACCC $19665^{\mathrm{T}}$ and M. septentrionale SDW014 ${ }^{\mathrm{T}}$ were $60.4 \%$ and $90.1 \%$, respectively, clearly indicating that genospecies VII belongs to $M$. septentrionale. In contrast, levels of DNADNA relatedness between strains CCBAU $83330^{\mathrm{T}}$, CCBAU $83306^{\mathrm{T}}$, CCBAU 83278 and the seven reference strains of recognized Mesorhizobium species were very low (Table 2). These results, as well as those of the sequence analyses, led to the conclusion that the strains of genomic species $\mathrm{V}$ and VI belong to three distinct novel species based on the recommendation of a threshold value of $70 \%$ DNA-DNA relatedness for species delineation (Wayne et al., 1987; Graham et al., 1991). The DNA G+C content values ranged from $57.23 \%$ to $57.86 \%$ with a mean value of $57.65 \%$ for genospecies $\mathrm{V}$, and $57.44 \%$ to $57.85 \%$ with a mean value of $57.51 \%$ for genospecies VI.

Strains representing the three novel species including strains CCBAU $83306^{\mathrm{T}}$, CCBAU 83521, CCBAU $83330^{\mathrm{T}}$, CCBAU 83345 and CCBAU 83278 and six type strains of related recognized species were chosen for phenotypic characterization. A total of 107 phenotypic features were examined using methods described previously (Gao et al., 1994). The characteristics examined included utilization of sole carbon and nitrogen sources; resistance to antibiotics (5, 50, 100 and $\left.300 \mu \mathrm{g} \mathrm{ml}^{-1}\right)$; tolerance to $\mathrm{NaCl}(1-5.0 \%$; $\mathrm{w} / \mathrm{v})$; production of catalase, urease, L-phenylalaninase and oxidase; the methyl blue reduction reaction, Nile blue reduction and nitrate reduction; litmus milk reaction and the $\mathrm{pH}$ and temperature ranges for growth. Analysis of cellular fatty acids was performed for strains CCBAU 83278, CCBAU $83330^{\mathrm{T}}$ and CCBAU $83306^{\mathrm{T}}$ according to methods described by Sasser (1990) and Tighe et al. (2000). The two novel species could be distinguished from each other and from the closely related species of the genus Mesorhizobium by several phenotypic characteristics (Table 3) and by their fatty acid contents (see Supplementary Table S1 in IJSEM Online).

Based upon all the results obtained in this study, we believe that genomic species V and VI represent three separate novel species in the genus Mesorhizobium. Since only one strain, CCBAU 83278, was identified as representing one of the novel species, a name is not yet proposed for this taxon. According to the current criteria for descriptions of rhizobial species, we propose two novel species, Mesorhizobium gobiense sp. nov., represented by genomic species $\mathrm{V}$ (type strain CCBAU $83330^{\mathrm{T}}$ ), and Mesorhizobium tarimense sp. nov. represented by genomic species VI (type strain CCBAU $83306^{\mathrm{T}}$ ).

Host range is an important feature for root- and/or stemnodule bacteria and cross-nodulation tests were performed with the representative strains CCBAU $83306^{\mathrm{T}}$ and CCBAU $83330^{\mathrm{T}}$ with the hosts of origin and the related hosts Astragalus membranaceus, Glycyrrhiza uralensis, Lotus corniculatus, Oxytropis glabra, Robinia pseudoacacia and 
Table 3. Distinctive features of $M$. gobiense sp. nov., M. tarimense sp. nov. and the closest related recognized species of the genus Mesorhizobium

Taxa: 1, CCBAU 83278; 2, M. gobiense sp. nov. CCBAU 83330 ${ }^{\mathrm{T}}$; 3, M. gobiense sp. nov. CCBAU 83346; 4, M. tarimense sp. nov. CCBAU 83306 ${ }^{\mathrm{T}}$; 5 , M. tarimense sp. nov. CCBAU 83321; 6, M. tianshanense CCBAU 3306 ${ }^{\mathrm{T}}$; 7, M. temperatum SDW018 ${ }^{\mathrm{T}}$; 8, M. mediterraneum USDA 3392 ${ }^{\mathrm{T}}$; 9 , M. septentrionale SDW014 ${ }^{\mathrm{T}}$; 10, M. amorphae ACCC $19665^{\mathrm{T}}$; 11, M. loti NZP $2213^{\mathrm{T}}$. +, Positive; -, negative.

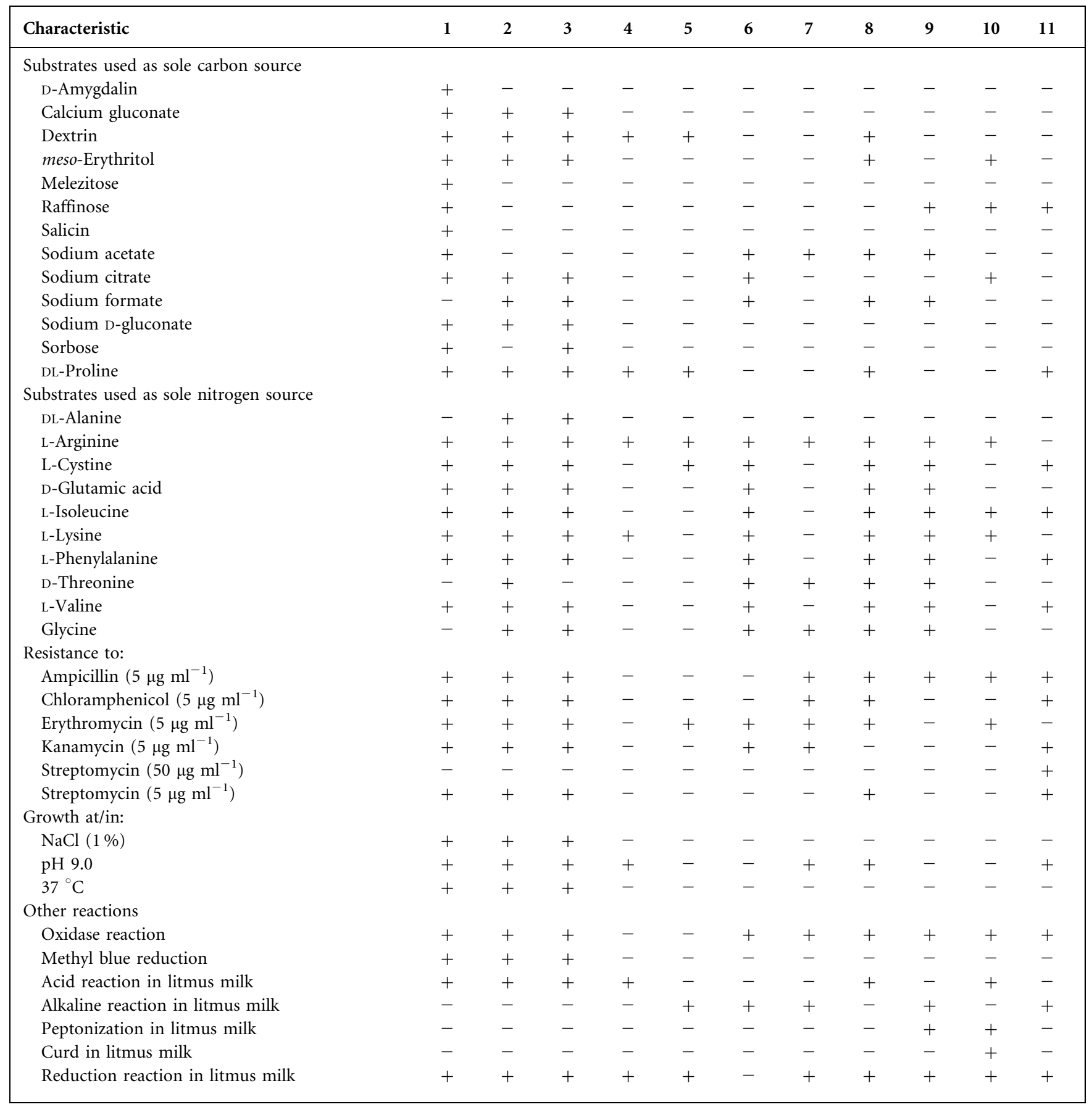

the recommended standard plant species Leucaena leucocephala, Phaseolus vulgaris, Pisum sativum and Medicago sativa (Graham et al., 1991). The seeds of the host plants were surface-sterilized, germinated and inoculated according to a standard procedure (Vincent, 1970). The inoculated seedlings were grown in Gibson tubes (Gibson,
1980) supplemented with a nitrogen-free plant nutrient solution (Brunel et al., 1996), while non-inoculated plants were used as controls. Three replicates were prepared for each treatment. Plants were incubated in a greenhouse under natural sunlight. After 45-60 days, the plants were harvested and the nodules were observed. The results 
showed that both strain CCBAU $83306^{\mathrm{T}}$ and CCBAU $83330^{\mathrm{T}}$ could nodulate Glycyrrhiza uralensis, Lotus corniculatus, Oxytropis glabra and Robinia pseudoacacia but could not nodulate Astragalus membranaceus, Leucaena leucocephala, Phaseolus vulgaris, Pisum sativum or Medicago sativa.

\section{Description of Mesorhizobium gobiense sp. nov.}

Mesorhizobium gobiense (go.bi.en'se. N.L. neut. adj. gobiense pertaining to the Gobi desert, where the strains reported in this study were isolated)

Gram-negative, aerobic, non-spore-forming rods that are $0.3-0.6 \mu \mathrm{m}$ wide by $1-3 \mu \mathrm{m}$ long. Colonies on YMA medium are circular, convex, white, opaque and usually have a diameter of $1-2 \mathrm{~mm}$ after 5-7 days incubation at $28{ }^{\circ} \mathrm{C}$. The optimum growth temperature is $25-30{ }^{\circ} \mathrm{C}$ and growth can take place at $37{ }^{\circ} \mathrm{C}$. Growth is inhibited at $10{ }^{\circ} \mathrm{C}$ or $60{ }^{\circ} \mathrm{C}$. The optimum $\mathrm{pH}$ for growth is $6-8$ and growth can take place at $\mathrm{pH} 5-9$. All strains grow on YMA in the presence of $1 \% \mathrm{NaCl}$. Able to utilize D-arabinose, calcium gluconate, dextrin, meso-erythritol, D-fructose, (+)-D-galactose, D-glucose, inositol, lactose, sodium malate, maltose, D-mannose, turanose, sodium pyruvate, L-rhamnose, sodium citrate, sodium D-gluconate, sodium succinate, sucrose, trehalose, D-xylose, DL-arginine, DLaspartic acid and DL-proline as sole carbon sources. Utilizes L-arginine, (+ )-L-aspartic acid, L-cystine, D-glutamic acid, (+)-L-glutamic acid, hypoxanthine, L-isoleucine, L-lysine, L-phenylalanine, L-valine, L-threonine and L-hydroxyproline as sole nitrogen sources. Does not utilize adipic acid, inulin, sodium hippurate, soluble starch, syringic acid, sodium tartrate, vanillic acid, glycine and L-methionine as sole carbon sources. Resistant to $5 \mu \mathrm{g} \mathrm{ml}^{-1}$ ampicillin, chloramphenicol, erythromycin, kanamycin and streptomycin. Catalase and oxidase activities are present, but L-phenylalaninase and urease activities are not. No reduction of nitrate or Nile blue, but reduction of methyl blue is observed. Acid and reduction reactions are produced in litmus milk.

The type strain is strain CCBAU $83330^{\mathrm{T}}\left(=\mathrm{LMG} 23949^{\mathrm{T}}=\right.$ HAMBI $2974^{\mathrm{T}}$ ). The DNA G $+\mathrm{C}$ content of the type strain is $57.86 \mathrm{~mol} \%$.

\section{Description of Mesorhizobium tarimense sp. nov.}

Mesorhizobium tarimense (ta.ri.men'se. N.L. neut. adj. tarimense referring to the Tarim basin, from where the strains reported in this study were isolated)

Gram-negative, aerobic, non-spore-forming rods that are $0.3-0.6 \mu \mathrm{m}$ wide by $1-3 \mu \mathrm{m}$ long. Colonies on YMA medium are circular, convex, white, opaque and usually have a diameter of 1-2 mm after 5-9 days growth at $28{ }^{\circ} \mathrm{C}$. The optimum growth temperature is $25-30{ }^{\circ} \mathrm{C}$ and no growth occurs at $10{ }^{\circ} \mathrm{C}$ or $37{ }^{\circ} \mathrm{C}$. The optimum $\mathrm{pH}$ for growth is $6-8$ and growth can take place on YMA plates at $\mathrm{pH}$. Does not grow on YMA in the presence of $1 \% \mathrm{NaCl}$.
Is able to utilize D-arabinose, dextrin, D-fructose, $(+)$-Dgalactose, D-glucose, inositol, lactose, sodium malate, maltose, D-mannose, turanose, sodium pyruvate, L-rhamnose, sodium succinate, sucrose, trehalose, D-xylose, DLarginine, DL-aspartic acid and DL-proline as sole carbon sources. Can use L-arginine, (+)-L-aspartic acid, $(+)$-Lglutamic acid, hypoxanthine, L-threonine and L-hydroxyproline as sole nitrogen sources. Does not utilize adipic acid, D-amygdalin, calcium gluconate, meso-erythritol, inulin, melezitose, raffinose, salicin, sodium acetate, sodium citrate, sodium formate, sodium D-gluconate, sodium hippurate, sorbose, soluble starch, syringic acid, sodium tartrate, vanillic acid, glycine or L-methionine as sole carbon sources. Does not utilize DL-alanine, D-glutamic acid, L-isoleucine, L-phenylalanine, D-threonine, L-valine or glycine as sole nitrogen sources. Resistant to $5 \mu \mathrm{g} \mathrm{ml}^{-1}$ erythromycin. Catalase production is detected but no production of oxidase, L-phenylalaninase or urease. No reduction of nitrate, methyl blue or Nile blue. Acid and reduction reactions are produced in litmus milk.

The type strain is CCBAU $83306^{\mathrm{T}}\left(=\mathrm{LMG} 24338^{\mathrm{T}}=\right.$ HAMBI $2973^{\mathrm{T}}$ ). The DNA G $+\mathrm{C}$ content of the type strain is $57.85 \mathrm{~mol} \%$.

\section{Acknowledgements}

We thank Professor Ge Hong Wei and Professor Fu Suo Zhang for their kind help with seed and nodule collections. We are also very grateful to two anonymous referees for their valuable comments. This work was supported by National Basic Research Program of China (2006CB100206), National Program for Basic S \& T Platform Construction (2005DKA21201-10) and National Natural Science Foundation of China (30670001 and 30400001). E.T.W. was supported by grants CGPI20060213 and CGPI20070538 authorized by IPN, Mexico.

\section{References}

Allen, O. N. \& Allen, E. K. (1981). The Leguminosae. A Source Book of Characteristics, Uses and Nodulation. Madison: University of Wisconsin Press.

Brunel, B., Rome, S., Ziani, R. \& Cleyet-Marel, J. C. (1996). Comparison of nucleotide diversity and symbiotic properties of Rhizobium meliloti populations from annual Medicago species. FEMS Microbiol Ecol 19, 71-82.

Chen, W. X., Yan, G. H. \& Li, J. L. (1988). Numerical taxonomic study of fast-growing soybean rhizobia and a proposal that Rhizobium fredii be assigned to Sinorhizobium gen. nov. Int J Syst Bacteriol 38, 392-397.

Chen, W. X., Li, G. S., Qi, Y. L., Wang, E. T., Yuan, H. L. \& Li, J. L. (1991). Rhizobium huakuii sp. nov., isolated from the root nodules of Astragalus sinicus. Int J Syst Bacteriol 41, 275-280.

Chen, W. X., Wang, E. T., Wang, S. Y., Li, Y. B., Chen, X. Q. \& Li, Y. (1995). Characteristics of Rhizobium tianshanense sp. nov., a moderately and slowly growing root nodule bacterium isolated from an arid saline environment in Xinjiang, People's Republic of China. Int J Syst Bacteriol 45, 153-159.

Chen, W. X., Tan, Z. Y., Gao, J. L., Li, Y. \& Wang, E. T. (1997). Rhizobium hainanense sp. nov., isolated from tropical legumes. Int $J$ Syst Bacteriol 47, 870-873. 
Cho, J. C. \& Tiedje, J. M. (2000). Biogeography and degree of endemicity of fluorescent Pseudomonas strains in soil. Appl Environ Microbiol 66, 5448-5456.

De Ley, J. (1970). Reexamination of the association between melting point, buoyant density, and chemical base composition of deoxyribonucleic acid. J Bacteriol 101, 738-754.

Gao, J. L., Sun, J. G., Li, Y., Wang, E. T. \& Chen, W. X. (1994). Numerical taxonomy and DNA relatedness of tropical rhizobia isolated from Hainan province of China. Int J Syst Bacteriol 44, 151-158.

Gao, J. L., Turner, S. L., Kan, F. L., Wang, E. T., Tan, Z. Y., Qiu, Y. H., Gu, J., Terefework, Z., Young, J. P. \& other authors (2004). Mesorhizobium septentrionale sp. nov. and Mesorhizobium temperatum sp. nov. isolated from Astragalus adsurgens growing in the northern regions of China. Int J Syst Evol Microbiol 54, 2003-2012.

Gibson, A. H. (1980). Methods for legumes in glasshouse and controlled environment cabinets. In Methods for Evaluating Biological Nitrogen Fixation, pp. 139-184. Edited by F. J. Bergersen. Wiley: New York.

Graham, P. H., Sadowsky, M. J., Keyser, H. H., Barnet, Y. M., Bradley, R. S., Cooper, J. E., De Ley, D. J., Jarvis, B. D. W., Roslycky, E. B. \& other authors (1991). Proposed minimal standards for the description of new genera and species of root- and stem-nodulating bacteria. Int J Syst Bacteriol 41, 582-587.

Han, T. X., Wang, E. T., Han, L. L., Chen, W. F., Sui, X. H. \& Chen, W. X. (2008). Molecular diversity and phylogeny of rhizobia associated with wild legumes native to Xinjiang, China. Syst Appl Microbiol 31, 287-301.

Haukka, K., Lindström, K. \& Young, J. P. (1998). Three phylogenetic groups of nodA and nifH genes in Sinorhizobium and Mesorhizobium isolates from leguminous trees growing in Africa and Latin America. Appl Environ Microbiol 64, 419-426.

Healy, M., Huong, J., Bittner, T., Lising, M., Frye, S., Raza, S., Schrock, R., Manry, J., Renwick, A. \& other authors (2005). Microbial DNA typing by automated repetitive-sequence-based PCR. J Clin Microbiol 43, 199-207.

Hurek, T., Wagner, B. \& Reinhold-Hurek, B. (1997). Identification of $\mathrm{N}_{2}$-fixing plant- and fungus-associated Azoarcus species by PCRbased genomic fingerprints. Appl Environ Microbiol 63, 4331-4339.

Jensen, M. A., Webster, J. A. \& Straus, N. (1993). Rapid identification of bacteria on the basis of polymerase chain reaction-amplified ribosomal DNA spacer polymorphisms. Appl Environ Microbiol 59, 945-952.

Jukes, T. H. \& Cantor, C. R. (1969). Evolution of protein molecules. In Mammalian Protein Metabolism, pp. 21-132. Edited by H. N. Munro. London: Academic Press.

Kimura, M. (1983). The Neutral Theory of Molecular Evolution. Cambridge: Cambridge University Press.

Kumar, S., Tamura, K. \& Nei, M. (2004). MEGA3: integrated software for molecular evolutionary genetics analysis and sequence alignment. Brief Bioinform 5, 150-163.

Laguerre, G., Mavingui, P., Allard, M. R., Charnay, M. P., Louvrier, P., Mazurier, S. I., Rigottier-Gois, L. \& Amarger, N. (1996). Typing of rhizobia by PCR DNA fingerprinting and PCR-restriction fragment length polymorphism analysis of chromosomal and symbiotic gene regions: application to Rhizobium leguminosarum and its different biovars. Appl Environ Microbiol 62, 2029-2036.

Marmur, J. (1961). A procedure for the isolation of deoxyribonucleic acid from microorganism. J Mol Biol 3, 208-218.

Marmur, J. \& Doty, P. (1962). Determination of the base composition of deoxyribonucleic acid from its thermal denaturation temperature. J Mol Biol 5, 109-118.
Navarro, E., Simonet, P., Normand, P. \& Bardin, R. (1992). Characterization of natural populations of Nitrobacter spp. using PCR/RFLP analysis of the ribosomal intergenic spacer. Arch Microbiol 157, 107-115.

Nick, G. \& Lindström, K. (1994). Use of repetitive sequences and the polymerase chain reaction to fingerprint the genomic DNA of Rhizobium galegae strains and to identify the DNA obtained by sonicating liquid cultures and root nodules. Syst Appl Microbiol 17, 265-273.

Ponsonnet, C. \& Nesme, X. (1994). Identification of Agrobacterium strains by PCR-RFLP analysis of pTi and chromosomal regions. Arch Microbiol 161, 300-309.

Rademaker, J. L., Hoste, B., Louws, F. J., Kersters, K., Swings, J., Vauterin, L., Vauterin, P. \& de Bruijn, F. J. (2000). Comparison of AFLP and rep-PCR genomic fingerprinting with DNA-DNA homology studies: Xanthomonas as a model system. Int J Syst Evol Microbiol 50, 665-677.

Rivas, R., Velázquez, E., Willems, A., Vizcaíno, N., Subba-Rao, N. S., Mateos, P. F., Gillis, M., Dazzo, F. B. \& Martínez-Molina, E. (2002). A new species of Devosia that forms a unique nitrogen-fixing root nodule symbiosis with the aquatic legume Neptunia natans (L. f.) Druce. Appl Environ Microbiol 68, 5217-5222.

Rzhetsky, A. \& Nei, M. (1993). Theoretical foundation of the minimum-evolution method of phylogenetic inference. Mol Biol Evol 10, 1073-1095.

Saitou, N. \& Nei, M. (1987). The neighbor-joining method: a new method for reconstructing phylogenetic trees. Mol Biol Evol 4, 406-425.

Sarita, S., Sharma, P. K., Priefer, U. B. \& Prell, J. (2005). Direct amplification of rhizobial nodC sequences from soil total DNA and comparison to nodC diversity of root nodule isolates. FEMS Microbiol Ecol 54, 1-11.

Sasser, M. (1990). Identification of bacteria by gas chromatography of cellular fatty acids, MIDI Technical Note 101. Newark, DE: MIDI Inc.

Scholla, M. H. \& Elkan, G. H. (1984). Rhizobium fredii sp. nov., a fast-growing species that effectively nodulates soybeans. Int J Syst Bacteriol 34, 484-486.

Swofford, D. L. (1993). PAUP: Phylogenetic Analysis Using Parsimony, version 3.1.1. Champaign, IL: Illinois Natural History Survey.

Tajima, F. \& Nei, M. (1984). Estimation of evolutionary distance between nucleotide sequences. Mol Biol Evol 1, 269-285.

Tamura, K. \& Nei, M. (1993). Estimation of the number of nucleotide substitutions in the control region of mitochondrial DNA in humans and chimpanzees. Mol Biol Evol 10, 512-526.

Tan, Z. Y., Xu, X. D., Wang, E. T., Gao, J. L., Martínez-Romero, E. \& Chen, W. X. (1997). Phylogenetic and genetic relationships of Mesorhizobium tianshanense and related rhizobia. Int J Syst Bacteriol 47, 874-879.

Tan, Z. Y., Kan, F. L., Peng, G. X., Wang, E. T., Reinhold-Hurek, B. \& Chen, W. X. (2001). Rhizobium yanglingense sp. nov., isolated from arid and semi-arid regions in China. Int J Syst Evol Microbiol 51, 909-914.

Thompson, J. D., Higgins, D. G. \& Gibson, T. J. (1994). CLUSTAL W: improving the sensitivity of progressive multiple sequence alignment through sequence weighting, positions-specific gap penalties and weight matrix choice. Nucleic Acids Res 22, 4673-4680.

Tighe, S. W., de Lajudie, P., Dipietro, K., Lindström, K., Nick, G. \& Jarvis, B. D. (2000). Analysis of cellular fatty acids and phenotypic relationships of Agrobacterium, Bradyrhizobium, Mesorhizobium, Rhizobium and Sinorhizobium species using the Sherlock Microbial Identification System. Int J Syst Evol Microbiol 50, 787-801. 
van Berkum, P., Beyene, D., Bao, G., Campbell, T. A. \& Eardly, B. D. (1998). Rhizobium mongolense sp. nov. is one of three rhizobial genotypes identified which nodulate and form nitrogen-fixing symbioses with Medicago ruthenica [(L.) Ledebour]. Int $J$ Syst Bacteriol 48, 13-22.

Vauterin, L. \& Vauterin, P. (1992). Computer-aided objective comparison of electrophoresis patterns for grouping and identification of microorganisms. Eur Microbiol 1, 37-41.

Versalovic, J., Schneider, M., de Brujin, F. J. \& Lupski, J. R. (1994). Genomic fingerprinting of bacteria using repetitive sequence-based polymerase chain reaction. Methods Mol Cell Biol 5, 25-40.

Vincent, J. M. (1970). Manual for the Practical Study of Root-Nodule Bacteria. IBP handbook 15. Oxford: Blackwell.

Vinuesa, P., Rademaker, J. L., de Bruijn, F. J. \& Werner, D. (1998). Genotypic characterization of Bradyrhizobium strains nodulating endemic woody legumes of the Canary Islands by PCR-restriction fragment length polymorphism analysis of genes encoding $16 \mathrm{~S}$ rRNA and 16S-23S rDNA intergenic spacers, repetitive extragenic palindromic PCR genomic fingerprinting, and partial $16 \mathrm{~S} \mathrm{rDNA}$ sequencing. Appl Environ Microbiol 64, 2096-2104.

Vinuesa, P., Silva, C., Lorite, M. J., Izaguirre-Mayoral, M. L., Bedmar, E. J. \& Martínez-Romero, E. (2005a). Molecular systematics of rhizobia based on maximum likelihood and Bayesian phylogenies inferred from $r r s$, atpD, recA and nifH sequences, and their use in the classification of Sesbania microsymbionts from Venezuelan wetlands. Syst Appl Microbiol 28, 702-716.

Vinuesa, P., Silva, C., Werner, D. \& Martínez-Romero, E. (2005b). Population genetics and phylogenetic inference in bacterial molecular systematics: the roles of migration and recombination in Bradyrhizobium species cohesion and delineation. Mol Phylogenet Evol 34, 29-54.

Wang, E. T., van Berkum, P., Sui, X. H., Beyene, D., Chen, W. X. \& Martínez-Romero, E. (1999). Diversity of rhizobia associated with
Amorpha fruticosa isolated from Chinese soil and description of Mesorhizobium amorphae sp. nov. Int J Syst Bacteriol 49, 51-65.

Wang, F. Q., Wang, E. T., Zhang, Y. F. \& Chen, W. X. (2006). Characterization of rhizobia isolated from Albizia spp. in comparison with microsymbionts of Acacia spp. and Leucaena leucocephala grown in China. Syst Appl Microbiol 29, 502-517.

Wang, F. O., Wang, E. T., Liu, J., Chen, Q., Sui, X. H., Chen, W. F. \& Chen, W. X. (2007). Mesorhizobium albiziae sp. nov., a novel bacterium nodulating Albizia kalkora in a subtropical region of China. Int J Syst Evol Microbiol 57, 1192-1199.

Wayne, L. G., Brenner, D. J., Colwell, R. R., Grimont, P. A. D., Kandler, O., Krichevsky, M. I., Moore, L. H., Moore, W. E. C., Murray, R. G. E. \& other authors (1987). International Committee on Systematic Bacteriology. Report of the ad hoc committee on reconciliation of approaches to bacterial systematics. Int J Syst Bacteriol 37, 463-464.

Wei, G. H., Wang, E. T., Tan, Z. Y., Zhu, M. E. \& Chen, W. X. (2002). Rhizobium indigoferae sp. nov. and Sinorhizobium kummerowiae sp. nov., respectively isolated from Indigofera spp. and Kummerowia stipulacea. Int J Syst Evol Microbiol 52, 2231-2239.

Wei, G. H., Tan, Z. Y., Zhu, M. E., Wang, E. T., Han, S. Z. \& Chen, W. X. (2003). Characterization of rhizobia isolated from legume species within the genera Astragalus and Lespedeza grown in the Loess Plateau of China and description of Rhizobium loessense sp. nov. Int J Syst Evol Microbiol 53, 1575-1583.

Xu, L. M., Ge, C., Cui, Z., Li, J. \& Fan, H. (1995). Bradyrhizobium liaoningense sp. nov., isolated from the root nodules of soybeans. Int $J$ Syst Bacteriol 45, 706-711.

Yao, Z. Y., Kan, F. L., Wang, E. T., Wei, G. H. \& Chen, W. X. (2002). Characterization of rhizobia that nodulate legume species of the genus Lespedeza and description of Bradyrhizobium yuanmingense sp. nov. Int J Syst Evol Microbiol 52, 2219-2230. 